\title{
Forecasting of Turkey's Electrical Energy Consumption using LSTM and GRU Networks
}

\section{LSTM ve GRU Ağları Kullanılarak Türkiye'nin Elektrik Enerjisi Tüketiminin Tahmin Edilmesi}

\author{
Osman Tayfun Bişkin ${ }^{1}$, Ahmet Çifci ${ }^{2 *}$ \\ Geliş / Received: 10/05/2021 \\ Revize / Revised: 01/10/2021 \\ Kabul / Accepted: 11/10/2021

\begin{abstract}
Energy demand management is particularly important for developing and emerging economies. Their energy consumptions increase significantly, depending on their growing economies. As a result of Turkey's rapid economic and population growth, electricity consumption is increasing. Electricity consumption forecasting plays an essential role for energy suppliers, consumers, and policy makers. Therefore, using models to accurately and reliably forecast future electricity consumption trends is a key issue for the planning and operation of electric power systems. This paper focused on forecasting electrical energy consumption by utilizing deep learning methods, i.e., Long Short-Term Memory (LSTM) and Gated Recurrent Unit (GRU) models, for time series data. One-hour and three-hour ahead forecasting are accomplished by using a historical dataset of electrical energy consumption in Turkey. The comparison results show that the GRU model is slightly better than that of the LSTM.
\end{abstract} \\ Our study also reveals that one-hour ahead predictions are more accurate than three-hour ahead predictions.
}

Keywords-Deep Learning, Electrical Energy Consumption, Forecasting, Gated Recurrent Unit, Long Short-Term Memory

$\overline{\mathbf{O Z Z}}$

Enerji talep yönetimi, gelişmekte olan ve yükselen ekonomiler için özellikle önemlidir. Büyüyen ekonomilerine bağlı olarak enerji tüketimleri önemli ölçüde artmaktadır. Türkiye'nin hızlı ekonomik ve nüfus artışının bir sonucu olarak elektrik tüketimi artmaktadır. Elektrik tüketimi tahmini enerji tedarikçileri, tüketiciler ve politika yapıcılar için önemli bir rol oynar. Bu nedenle, gelecekteki elektrik tüketim eğilimlerini doğru ve güvenilir bir şekilde tahmin etmek için modellerin kullanılması, elektrik güç sistemlerinin planlanması ve işletilmesi için kilit bir konudur. Bu makale, zaman serisi verileri için Uzun Kısa-Süreli Bellek (Long Short-Term Memory-LSTM) ve Kapılı Yinelemeli Birim (Gated Recurrent Unit-GRU) modelleri gibi derin öğrenme yöntemlerini kullanarak elektrik enerjisi tüketimini tahmin etmeye odaklanmıştır. Türkiye'de elektrik enerjisi tüketiminin geçmişe dönük veri seti kullanılarak bir saatlik ve üç saatlik ileriye yönelik tahminler gerçekleştirilmiştir. Karşılaş̧ırma sonuçları, GRU modelinin LSTM modelinden biraz daha iyi olduğunu göstermektedir. Çalışmamız ayrıca, bir saat ileri tahminlerin üç saat ileri tahminlerden daha doğru olduğunu ortaya koymaktadır.

Anahtar Kelimeler-Derin Öğrenme, Elektrik Enerji Tüketimi, Tahmin, Kapılı Yinelemeli Birim, Uzun Kısa-Süreli Bellek

1İletişim: tbiskin@mehmetakif.edu.tr (https://orcid.org/0000-0002-2326-9438)

Elektrik-Elektronik Mühendisliği Bölümü, Burdur Mehmet Akif Ersoy Üniversitesi, 15030, Burdur, Türkiye

2*Sorumlu yazar iletișim: acifci@mehmetakif.edu.tr (https://orcid.org/0000-0001-7679-9945)

Elektrik-Elektronik Mühendisliği Bölümü, Burdur Mehmet Akif Ersoy Üniversitesi, 15030, Burdur, Türkiye 


\begin{tabular}{|c|c|c|}
\hline & $\begin{array}{l}\text { BŞEÜ Fen Bilimleri Dergisi } \\
8(2), 656-667,2021\end{array}$ & $\begin{array}{r}\text { BSEU Journal of Science } \\
\text { https://doi.org/10.35193/bseufbd.935824 }\end{array}$ \\
\hline & & 2458-7575 (https://dergipark.org.tr/tr/pub/bseufbd) \\
\hline
\end{tabular}

\section{INTRODUCTION}

Electrical energy, one of the secondary energy sources, is produced by converting primary sources of energy, such as petroleum, coal, natural gas, nuclear power, hydraulic, biomass, tides, solar, and wind [1]. While the first area of electrical energy use, a widely used and increasingly demanding energy source, is lighting, it is also widely used today in areas such as industry, communication, transportation, medicine, security, and aerospace. Global demand for electricity consumption is increasing rapidly. There are rising concerns over the health, and environmental impacts of electricity generation, the limited resources used in electricity generation, irresponsible and unlimited use of these resources and the inability to store electricity. Energy generation, transmission, and distribution facilities need to be planned for the future in order to meet the growing energy demand. On the other hand, environmental impacts such as toxic pollution, damage to public health, and global warming emissions bring the necessity to reduce electricity consumption.

Turkey has an important role as a bridge between resources in the Middle East, the Caspian Sea, and the demand center, Europe. This leads Turkey to become a regional energy hub and a corridor [2,3]. Turkey, with a growing population and economy, faces increasing consumption of energy, particularly for electricity, day by day. According to the last census on 31st December 2020, Turkey's population is 83,614,362 [4].Turkey has the world's 20th-largest nominal gross domestic product [5] and 13th-largest purchasing power parity [6-8].Turkey's total electricity consumption is 231.10 billion $\mathrm{kWh}$ per year. The per capita average electricity consumption is approximately $2770 \mathrm{kWh}$ [9]. The development of electricity consumption in Turkey over the years is shown in Figure 1.

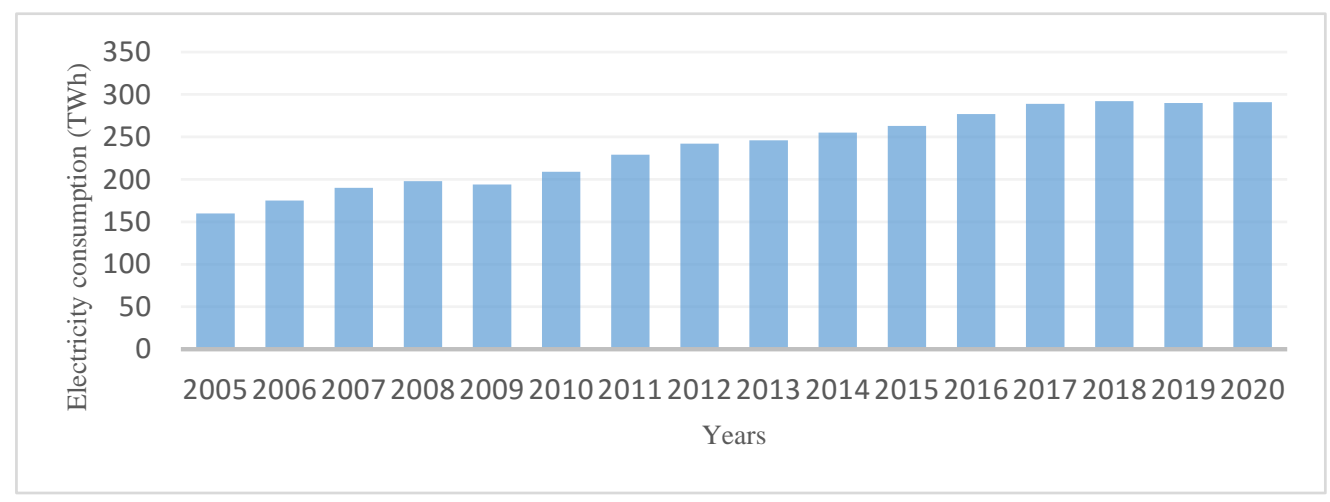

Figure1. Turkey's electricity consumption for the period of 2005-2020

Turkey is presently an energy importer. This situation negatively affects the Turkish economy and the current account balance deficit. Under these circumstances, regular plans should be made in electric power systems to prevent potential bottlenecks and various consumption estimation approaches to identify the electricity consumption level and the impact of factors that affect electricity consumption. Energy-dependent countries such as Turkey need to perform sensitive and realistic electricity demand forecasting studies. Forecasts that are not sensitive and realistic can be harmful both for the national economy and the daily life of society [10]. For this reason, using methods to forecast future electricity consumption trends accurately is an essential issue for power generation and distribution systems [11].

There are many several studies in the literature for Turkey's electricity consumption or demand forecasting with different applications such as time series models [12-15], grey prediction approaches [16-18], regression analyses[12, 19-24], adaptive network based fuzzy inference systems (ANFIS), auto-regressive moving average (ARMA) and auto-regressive integrated moving average (ARIMA) models [25-29], genetic algorithm [30, 31], fuzzy logic [29,32], optimization algorithms [33,34] and artificial neural network (ANN) $[12,15,18,21,25,35$ 43]. Table 1 below provides summary information related to the studies for Turkey's electricity consumption or demand forecasting. 
Table 1. Overview of the studies on electricity consumption or demand forecasting of Turkey

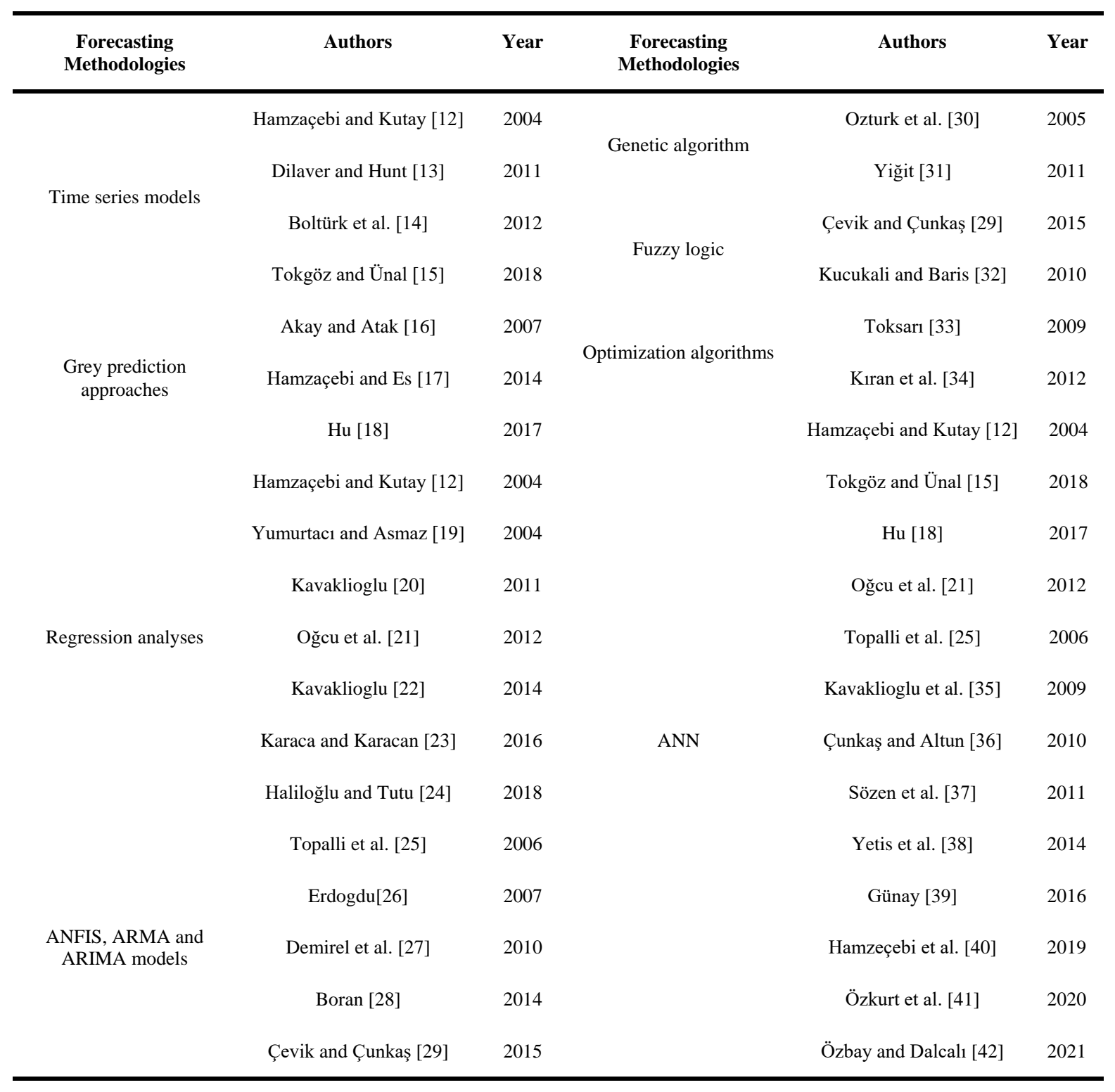

Recurrent Neural Networks (RNNs) are among the most widespread neural network architectures in stateof-the-art artificial neural networks. In the deep learning process, RNNs are suited for solving sequence problems. There are several variants of the RNN model, such as bidirectional RNN [43], clockwork RNN [44], GRU [45] and LSTM [46]. Despite the extensive research carried out in Turkey's electricity consumption or demand forecasting area, to the best of our knowledge, there is no too much work taking advantage of RNNs, a class of ANNs. Tokgöz and Ünal [15] presented a time series forecasting using RNN, LSTM and GRU models for electricity load in Turkey. In order to learn about the changes of consumption depending on time, the features of hour, day of the week and whether it is working day were used. In addition, the consumption value of twenty-four hours ago, the average consumption value of the last twenty-four hours and the consumption data of the same hour one week ago were used. Results revealed that the best performance was achieved with the 3-layered GRU model. Similarly, another study presented in [41] used the LSTM model for Turkey's twenty-four hours' electricity consumption forecasting. The electricity consumption data between June 2016 and July 2020 was used. They showed that their model gives better results than Energy Market Management Inc. (EPİAŞ). Moreover, Özbay and Dalcalı [42] attained a short-term consumption forecasting during the COVID-19 pandemic period using nonlinear 
autoregressive (NARX) and LSTM. Between January and April 2019 electricity consumption data were used. Results proved that the LSTM method was better than the NARX.

Storing a large amount of electricity is not possible in today's technology. Therefore, the generation of electricity in specific time intervals must match the need for consumption [47]. In order to supply uninterruptible electrical energy to users, the electricity supply is increased or decreased according to the demand [15]. The amount of generation and consumption of electricity needed is determined by market participants. In this way, the amount of generation matches that of consumption, and the price of electricity is finalized through the energy market (EPIAŞ) in Turkey [41]. Therefore, forecasting the consumption of electrical energy is important for market participants to determine the generation and the price of electricity. Studies about forecasting consumption can be categorized into two classes according to the length of time ahead of being predicted in literature. These classes are named long-term forecasting and short-term forecasting. If the length of time being predicted is in the interval from one-hour to 7-day, this is called short-term forecasting. On the other hand, if one tries to forecast the next season or years, then it will be called long-term forecasting. In this study, we are interested in short-term consumption forecasting. For this purpose, one-hour and three-hour ahead forecasting are accomplished by using a historical dataset of electrical energy consumption in Turkey. In this paper, we employed deep learning-based methods, LSTM and GRU methods, to forecast the electricity consumption in Turkey. The performance of methods employed in this paper is evaluated by using performance metrics such as Root-Mean-Square Error (RMSE), Normalized Root-Mean-Square Error (NRMSE), Root Mean Squared Log Error (RMSLE), and Mean Absolute Percentage Error (MAPE).

The remainder of the paper is arranged as follows: Section 2 provides a brief introduction about the models including the LSTM, and the GRU. Section 3 includes the dataset, and numerical experimental results. Finally, the paper is concluded in Section 4.

\section{METHODS AND MODELS}

\section{A. Problem Statement}

In this study, we are concerned with forecasting electrical energy consumption by employing deep learning methods. Forecasting can be defined as a process of predicting future values of a given time-series data using its historical values. Let $\mathbf{x}=\left[\begin{array}{lll}x_{1} & \ldots & x_{T}\end{array}\right]$ be a sequence representing a time series data with $x_{t} \in \mathbb{R}^{d}$ where $d$ is the number of dimensions of time-series data, at time $t$. Then, the aim of forecasting process is to predict the corresponding future values of data, $\mathbf{x}=\left[\begin{array}{lll}x_{T} & \ldots & x_{T+k}\end{array}\right]$, where $k$ represents the number of future values to be predicted. In this paper, LSTM and GRU models are employed for forecasting Turkey's electrical energy consumption, and we compare the performance of mentioned models in terms of performance metrics.

\section{B. LSTM Model}

RNN models have been utilized for time series applications that demonstrate temporal dependencies [48]. However, in case of existing long-term temporal dependencies, vanishing gradient problem degrade the capability of RNN networks. Therefore, LSTM was proposed in order to tackle the vanishing gradient problem [46]. Three gates, named input, output, and forget gates, control the information flow inside the LSTM layers [49]. The flow of input and output activation information is controlled by input gates and output gates, respectively. In other respects, forget gates are utilized to reset the memory of the cell in case the cell memory is not needed anymore [49]. The internal architecture of the LSTM unit is demonstrated in Figure 2.

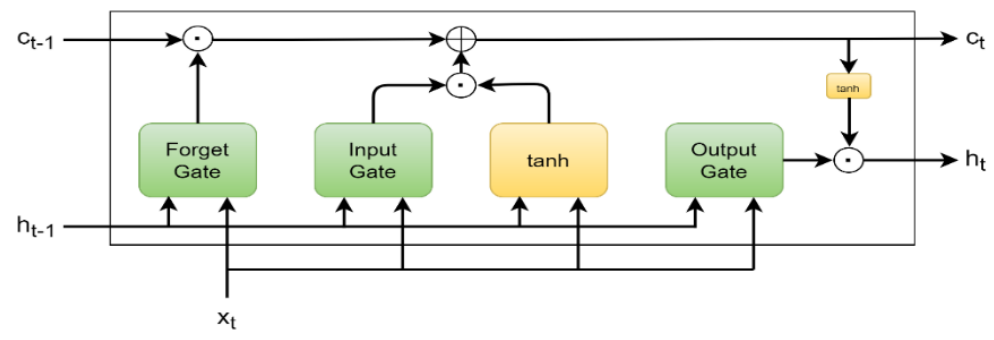

Figure 2. Internal architecture of an LSTM unit 
Input time-series data at aiven time $t$ is represented by $x_{t}$. Let $W_{i}, W_{o}$, and $W_{f}$ denote input, output, and forget weight parameters, respectively. Then, input $\left(i_{t}\right)$, output $\left(o_{t}\right)$, and forget gates $\left(f_{t}\right)$ in LSTM layer are written as follows:

$$
\begin{aligned}
& i_{t}=\sigma\left(W_{i}\left[h_{t-1}, x_{t}\right]+b_{i}\right) \\
& o_{t}=\sigma\left(W_{o}\left[h_{t-1}, x_{t}\right]+b_{o}\right) \\
& f_{t}=\sigma\left(W_{f}\left[h_{t-1}, x_{t}\right]+b_{f}\right)
\end{aligned}
$$

In (1), $b_{i}, b_{o}$, and $b_{f}$ represent bias parameters. $h_{f}$ and $h_{t}$ are hidden state vectors (also known as output state) at the time step $t$. In (1), $\sigma(\cdot)$ denotes the sigmoid activation function. In the LSTM layer, the hidden state $\left(h_{t}\right)$ and cell state $\left(c_{t}\right)$ at the time step $t$ is given as

$$
\begin{aligned}
& c_{t}=i_{t} \odot \widetilde{c_{t}}+f_{t} \odot c_{t-1} \\
& h_{t}=o_{t} \odot \tanh \left(c_{t}\right)
\end{aligned}
$$

Here $\odot$ denotes the Hadamard product operation and $\tanh (\cdot)$ function is given as the hyperbolic tangent function. $\tilde{c}_{t}$ given in (2) is written as follows:

$$
\tilde{c}_{t}=\tanh \left(W_{c}\left[h_{t-1}, x_{t}\right]+b_{c}\right)
$$

where $W_{c}$ and $b_{c}$ represent weight and bias parameters, respectively.

\section{GRU Model}

In order to simply the LSTM model by decreasing the number of parameters, another architecture named GRU was proposed as a variant of LSTM [45,48,50,51]. While LSTM architecture has three gates, GRU has two gates: update and reset gates. The update gate is a kind of combination of input and forget gates given in LSTM. Memory transferred to the new state is controlled by the update gate. The function of the reset gate is similar to the forget gate in LSTM. The reset gate is responsible to forget the past information which is not used anymore. Figure 3 shows the architecture of the GRU unit.

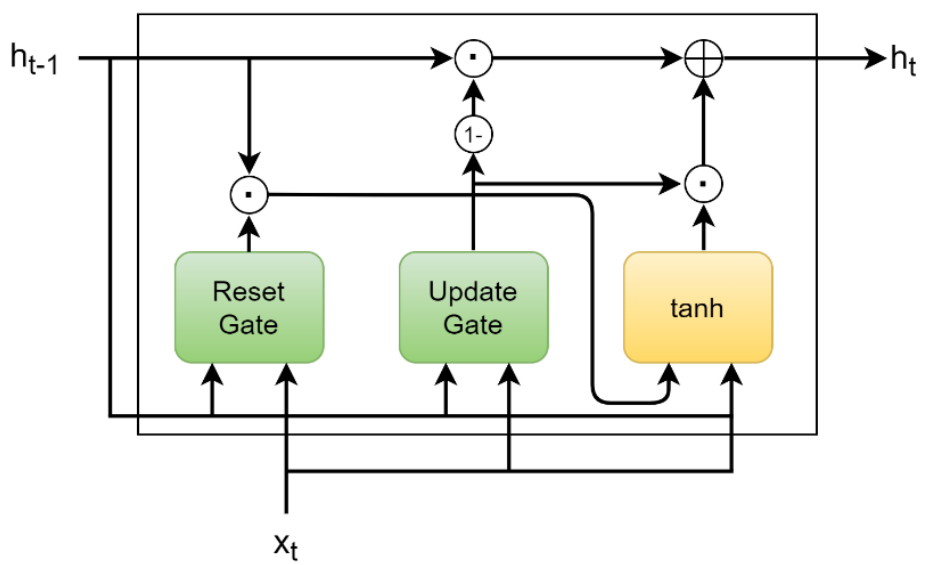

Figure 3. Internal architecture of a GRU unit

The update $\left(u_{t}\right)$ and reset gates $\left(r_{t}\right)$ in GRU is given as follows:

$$
u_{t}=\sigma\left(W_{u}\left[h_{t-1}, x_{t}\right]+b_{u}\right)
$$




$$
r_{t}=\sigma\left(W_{r}\left[h_{t-1}, x_{t}\right]+b_{r}\right)
$$

In (5) and (6), $W_{u}$ and $W_{r}$ denote the update and reset weight parameters, respectively. In addition, $b_{u}$ and $b_{r}$ represents the bias parameters. $h_{t}$ is defines as the hidden state vector (also known as output state vector) at the time step $t$. We can write the hidden state $\left(h_{t}\right)$ at the time step $t$ as follows

$$
h_{t}=u_{t} \odot \tilde{h}_{t}+\left(1-u_{t}\right) \odot c_{t-1}
$$

where $\tilde{h}_{t}$ above is written as

$$
\tilde{h}_{t}=\tanh \left(W_{h}\left[r_{t} \odot h_{t-1}, x_{t}\right]+b_{h}\right.
$$

Here, $W_{h}$ and $b_{h}$ are the weight and bias parameters, respectively.

\section{Performance Metrics}

The performance of LSTM and GRU models are evaluated by using performance metrics such as RMSE, NRMSE, RMSLE, and MAPE. Let a vector $\mathbf{y}$ be the future values of the sequence $\mathbf{x}$ such that $\mathbf{y}=\tilde{\mathbf{x}}=\left[\begin{array}{lll}\mathrm{x}_{\mathrm{T}} & \ldots & \mathrm{x}_{\mathrm{T}+\mathrm{k}}\end{array}\right]$. Then, $y_{i}$ and $\hat{y}_{i}$ represent actual and predicted values, respectively. Thus, the mentioned performance metrics is given as follows:

$$
\begin{aligned}
& \text { RMSE }=\sqrt{\frac{1}{n} \sum_{i=0}^{n-1}\left(y_{i}-\hat{y}_{i}\right)^{2}} \\
& \text { NRMSE }=\frac{\text { RMSE }}{y_{\text {max }}-y_{\text {min }}} \\
& \text { RMSLE }=\sqrt{\frac{1}{n} \sum_{i=0}^{n-1}\left(\log \left(y_{i}\right)-\log \left(\hat{y}_{i}\right)\right)^{2}} \\
& \text { MAPE }=\frac{100}{n} \sum_{i=0}^{n-1}\left|\frac{y_{i}-\hat{y}_{i}}{y_{i}}\right|
\end{aligned}
$$

In (10), $y_{\max }$ and $y_{\min }$ indicate the maximum and minimum element in the vector $\mathbf{y}$, respectively. On the other hand, $\log ($.$) represents the natural logarithm operator in (11). RMSLE metric given in (11) is extensively$ utilized for evaluating model performance in regression problems because of its robustness to outliers [50].

\section{RESULTS}

\section{A. Dataset}

Dataset used in this paper for forecasting of electrical energy consumption were obtained from EPİAŞ in [52]. Dataset includes electrical energy consumption values in terms of MWh (megawatt hour) from December, 312015 at 00:00 am to March, 2 2021.Energy consumption values from October, 30, 2019 at 00:00 am to October, 302020 at 00:00 am, that is one year, are used as training data for models. The amount of training data is about $\% 80$ of the whole time series dataset. On the other hand, the time interval from October, 31, 2020 to December, 31,2020 is chosen as a validation part of the dataset. In order to measure the performance of models, a predefined section of time series data is utilized as a test dataset. This part of time series data has never been preserved to the model during its training progress. Hourly energy consumption values from January, 12021 to March, 22021 are defined as test data used to test the trained model and measure the performance of models in terms of predefined performance metrics. Figure 4 shows time series data of electrical energy consumption in Turkey. 


\begin{tabular}{|c|c|c|}
\hline & $\begin{array}{l}\text { BŞEÜ Fen Bilimleri Dergisi } \\
8(2), 656-667,2021\end{array}$ & $\begin{array}{r}\text { BSEU Journal of Science } \\
\text { https://doi.org/10.35193/bseufbd.935824 }\end{array}$ \\
\hline 0 & & 2458-7575 (https://dergipark.org.tr/tr/pub/bseufbd) \\
\hline
\end{tabular}

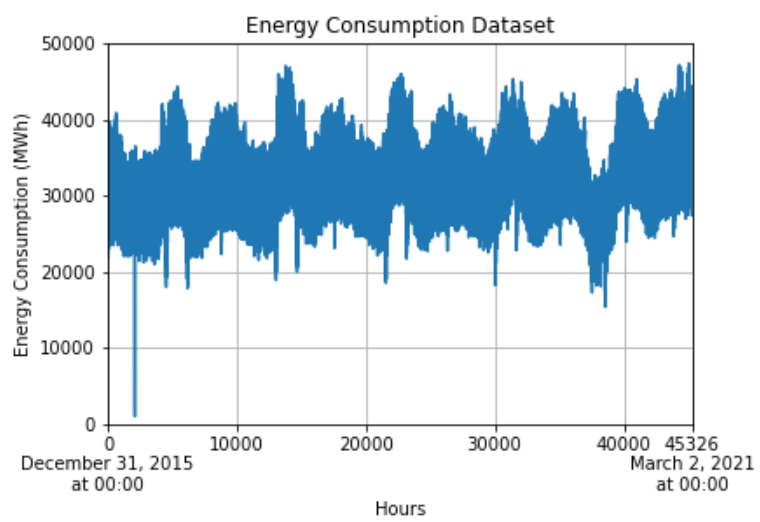

(a)

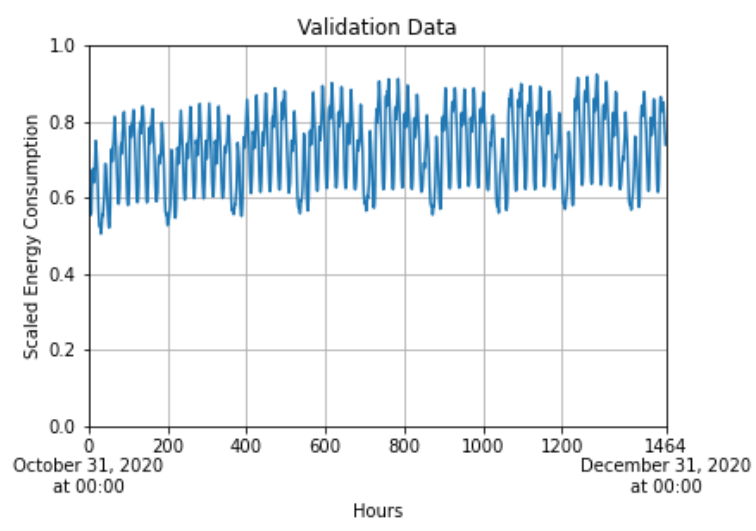

(c)

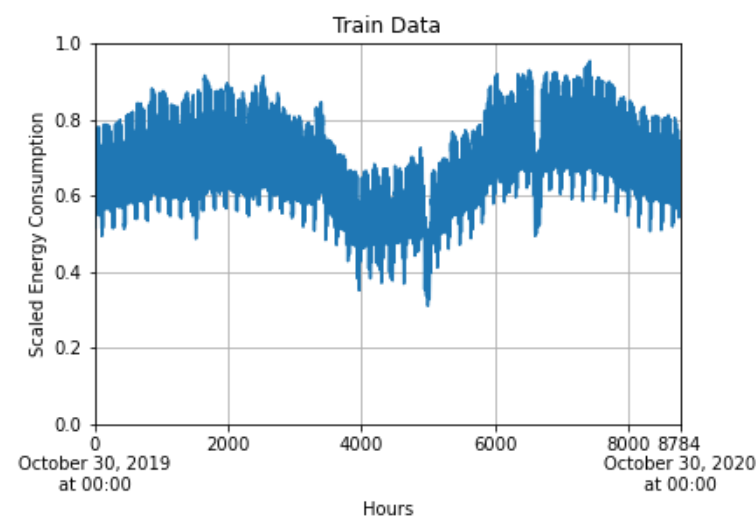

(b)

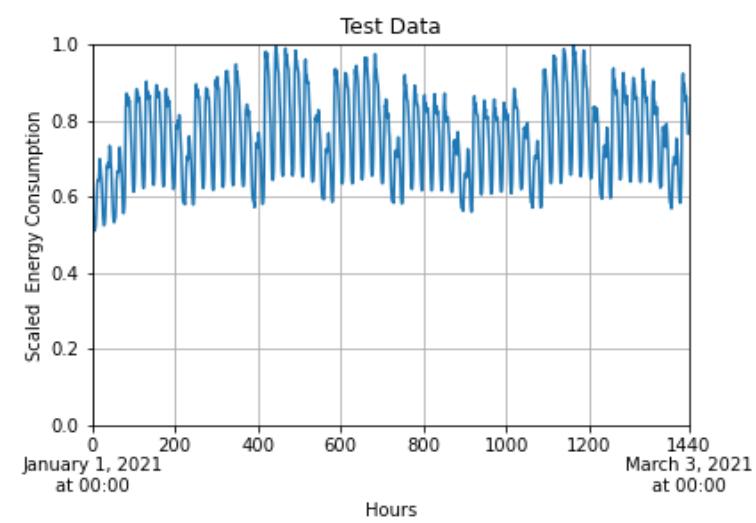

(d)

Figure 4. (a) Electrical energy consumption in Turkey in terms of MWh and (b) train data, (c) validation data, and (d) test data in terms of scaled values.

In Figure 4(a), energy consumption values in terms of MWh are given from December, 312015 at 00:00 am to March, 2 2021. In order to utilize the data for model training, time series data originally given in terms of MWh values are scaled into the range [0,1]. Therefore, train, validation and test data presented in Figure 4(b), (c), and (d) are represented between 0 and 1 . In addition, statistics of the database such as minimum (min), maximum (max), mean, median, standard deviation (Std), skew, and kurtosis values of data are given in Table 2.

Table 2. Summary of electrical energy consumption (MWh) dataset for Turkey.

\begin{tabular}{ccccccc}
\hline Min & Max & Mean & Median & Std & Skew & Kurtosis \\
\hline 949.63 & $47,427.3800$ & $32,909.1161$ & $33,030.1150$ & $5,077.4230$ & -0.0045 & -0.5127 \\
\hline
\end{tabular}

\section{B. Numerical Experiments}

All the simulations are performed on a Colab (Colaboratory) Platform provided by Google. GPU, provided by Colab Platform, is also utilized in order to speed up the model training. Tensoflow v2.3.0 and Keras v2.4.3 libraries are used for model training. In our numerical experiments, a four-layer network is used for LSTM and GRU models. All networks have three layers, each of which has 300 hidden units, and a dense layer. We chose the mean squared error (MSE) metric as the loss function of the model during the training process. In order to minimize the loss function, that is MSE of the loss, Adam optimizer is utilized with learning rate $1 \mathrm{r}=0.0001$ during the training of models. Training parameters are determined by employing various parameter values. Then, the values which result the best prediction performance are selected for model parameters. To find the optimal parameters for models, we search the hidden units in $\{50,100,150,200,250,300,350,400,450,500\}$ and learning rate, $\operatorname{lr}$, in $\left\{10^{-2}, 5 \times 10^{-3}, 10^{-3}, 5 \times 10^{-4}, 10^{-4}, 10^{-5}\right\}$ on the validation set. 


\begin{tabular}{|c|c|c|}
\hline & $\begin{array}{l}\text { BŞEÜ Fen Bilimleri Dergisi } \\
8(2), 656-667,2021\end{array}$ & $\begin{array}{r}\text { BSEU Journal of Science } \\
\text { https://doi.org/10.35193/bseufbd.935824 }\end{array}$ \\
\hline & & 2458-7575 (https://dergipark.org.tr/tr/pub/bseufbd) \\
\hline
\end{tabular}

In numerical examples, one hour and three-hour ahead forecasting are accomplished using electrical energy consumption in the last 24 hours and 48 hours. Therefore, the time step parameters of models are determined by the historical data length used for forecasting. Thus, we set the time step value to 24 and 48 for using the last 24 hours and 48 hours, respectively.

In the experiments, one hour ahead forecast of electrical energy consumption in Turkey is accomplished by employing the LSTM and GRU models and the performance of these models are evaluated by using the aforementioned performance metrics. Figures5, 6, 7, and 8 show the predicted and actual energy consumption values in Turkey from January, 12021 to March, 3 2021. One-hour ahead prediction results given in Figure 5 and Figure 6 are accomplished by using the energy values for the last 24 and 48 hours, respectively. On the other hand, Figure 7 and Figure 8 represent the three-hour ahead prediction for the last 24 and 48 hours, respectively.

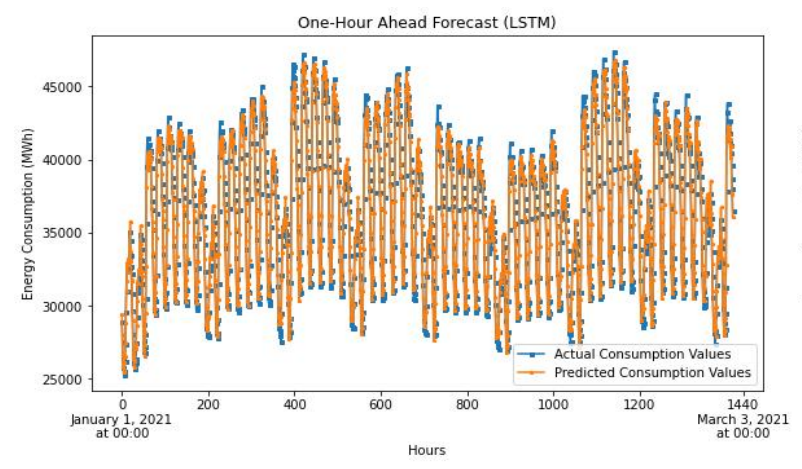

(a)

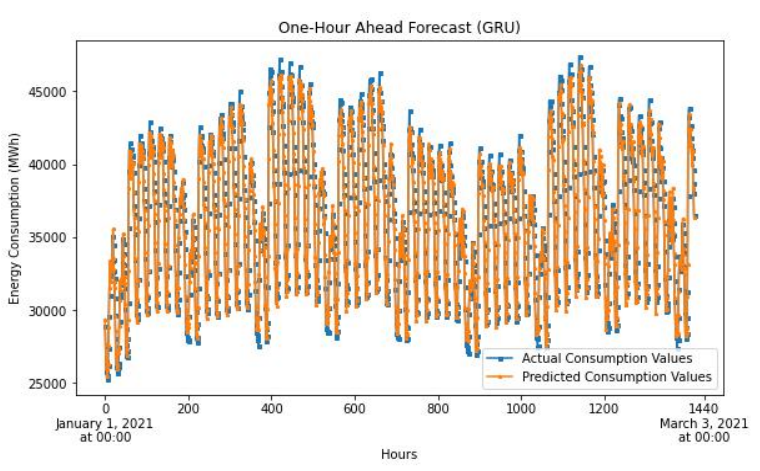

(b)

Figure 5.One-hour ahead prediction using last 24 hours by employing a) LSTM and b) GRU.

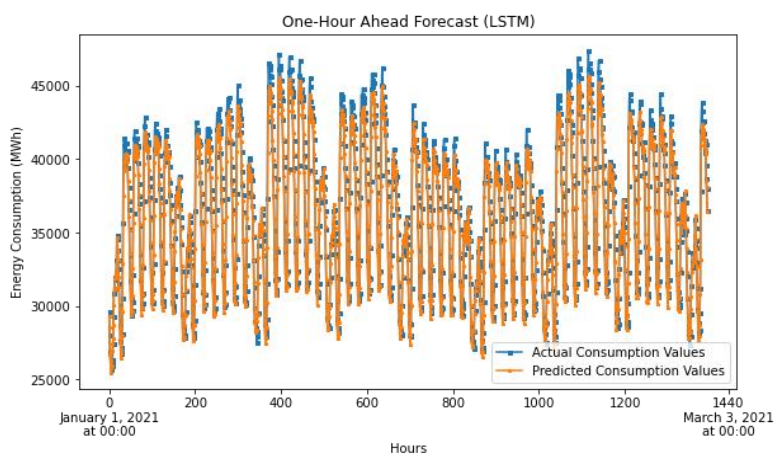

(a)

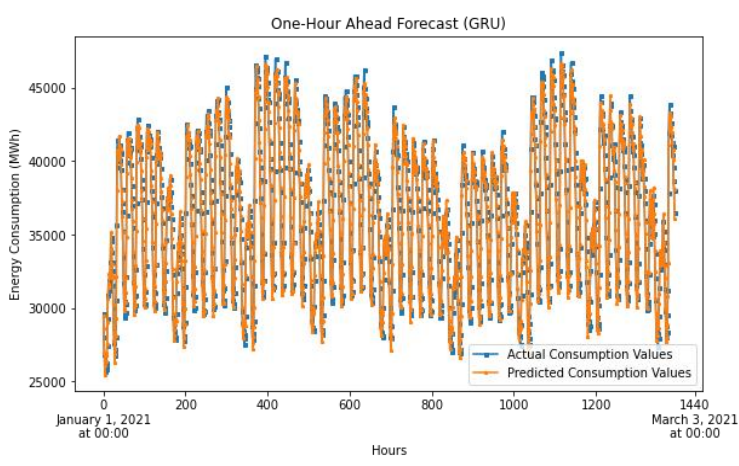

(b)

Figure 6. One-hour ahead prediction using last 48 hours by employing a) LSTM and b) GRU.

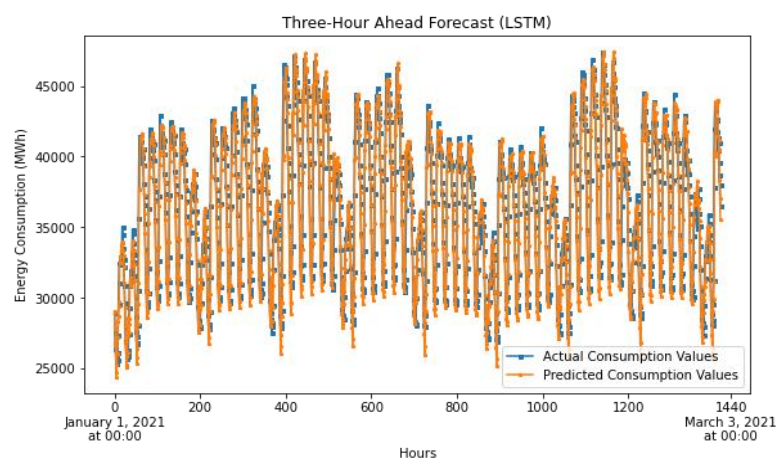

(a)

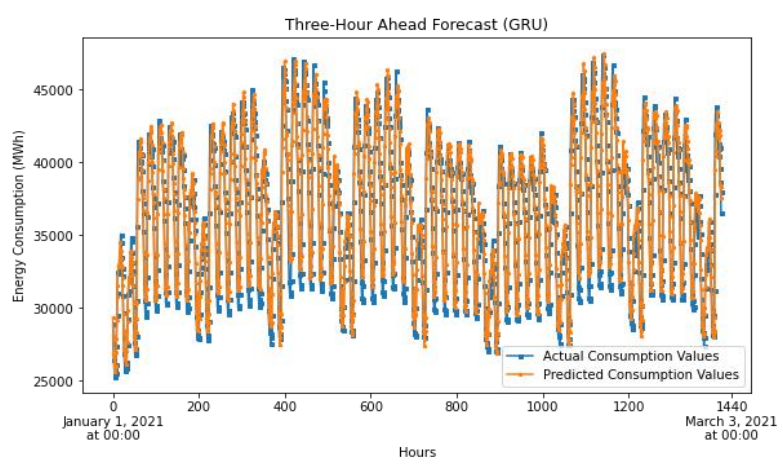

(b)

Figure 7.Three-hour ahead prediction using last 24 hours by employing a) LSTM and b) GRU. 


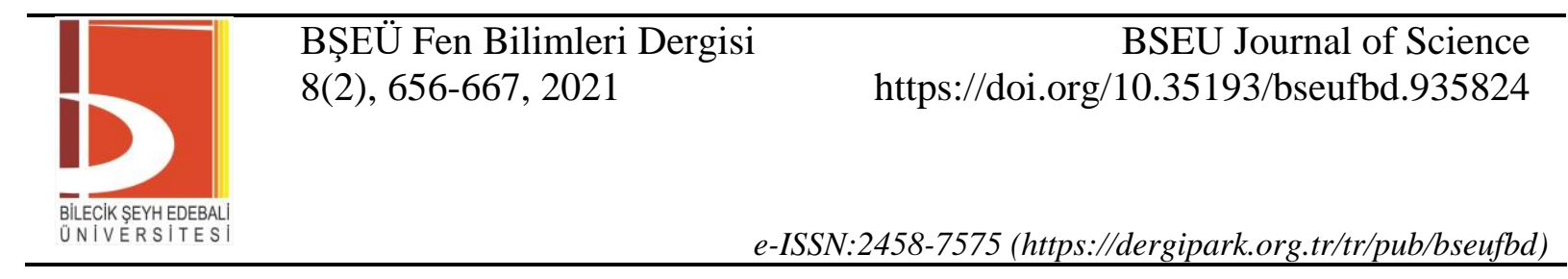

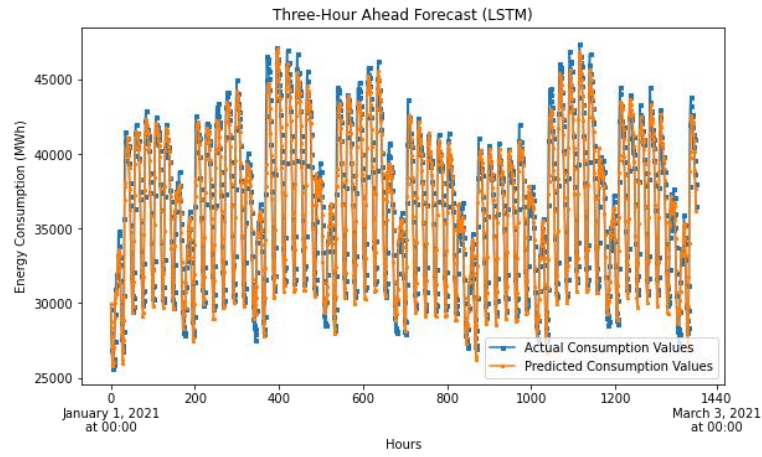

(a)

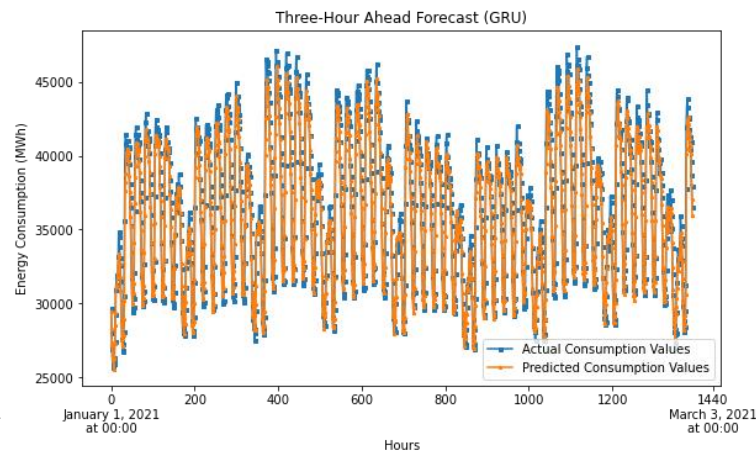

(b)

Figure 8. Three-hour ahead prediction using last 48 hours by employing a) LSTM and b) GRU.

The results are also presented in Table 3. From Table 3, we can see that the GRU model performs slightly better than the LSTM model by achieving lower RMSE, NRMSE, RMSLE, and MAPE values for all simulation scenarios. It can be seen from Table 3 that the error in one-hour ahead predictions is lower than three-hour ahead predictions as expected. In addition, energy consumption forecasting made by using the last 48 hours performs better than the forecasting using the last 24 hours in terms of the above performance metrics. However, one-hour ahead energy consumption forecasting made by utilizing the previous 48 hours outperforms the one-hour ahead forecasting using the previous 24 hours.

Table 3. Numerical results of the experiment

\begin{tabular}{lcccccc}
\hline & & Model & RMSE & NRMSE & RMSLE & MAPE \\
\hline \multirow{2}{*}{ Last 24 Hours } & \multirow{2}{*}{ One-Hour Ahead } & GRU & 18.444956 & 0.000865 & 0.000512 & 1.400022 \\
& & LSTM & 21.785292 & 0.001021 & 0.000593 & 1.687609 \\
\multirow{2}{*}{ Last 24 Hours } & Three-Hour Ahead & GRU & 106.764423 & 0.004878 & 0.002977 & 8.230357 \\
& & LSTM & 115.332663 & 0.005003 & 0.003115 & 8.169246 \\
\multirow{2}{*}{ Last 48 Hours } & \multirow{2}{*}{ One-Hour Ahead } & GRU & 18.526120 & 0.000874 & 0.000515 & 1.328526 \\
& & LSTM & 19.274565 & 0.000954 & 0.000510 & 1.327189 \\
\multirow{2}{*}{ Last 48 Hours } & \multirow{2}{*}{ Three-Hour Ahead } & GRU & 85.085281 & 0.004152 & 0.002337 & 5.602366 \\
& & LSTM & 94.676438 & 0.004446 & 0.002587 & 6.433359 \\
\hline
\end{tabular}

In Table 4, both training and prediction times of LSTM and GRU models are given. In order to calculate the computation times, Monte Carlo experiments were performed. For this purpose, 10 Monte Carlo trials were performed and the average values of independent computation times are calculated. We can see from the table that, GRU model performs better than the LSTM model because it terminates in less computation time.

Table 4. The computation time of LSTM and GRU models

\begin{tabular}{lccccc}
\hline & & \multicolumn{2}{c}{ Training Time (sec.) } & \multicolumn{2}{c}{ Prediction Time (sec.) } \\
& & LSTM & GRU & LSTM & GRU \\
\hline Last 24 Hours & One-Hour Ahead & 3555.07 & 2652.55 & 1.40 & 1.15 \\
Last 24 Hours & Three-Hour Ahead & 3809.56 & 2794.73 & 1.23 & 1.87 \\
Last 48 Hours & One-Hour Ahead & 7008.25 & 5208.84 & 1.34 & 1.11 \\
Last 48 Hours & Three-Hour Ahead & 7102.75 & 5185.91 & 0.41 & 0.38 \\
\hline
\end{tabular}

In Figure 9, to compare the forecasting performances of GRU and LSTM networks in terms of RMSE, NRMSE, RMSLE, and MAPE metrics, their performances are plotted together with one-hour and three-hour ahead prediction results. Looking at Figure 9, we can see that the prediction results obtained by employing the GRU 
network are slightly better than the LSTM network in terms of the aforementioned metrics. In addition, one-hour ahead forecasting results are more accurate than three-hour ahead forecasting results as expected.
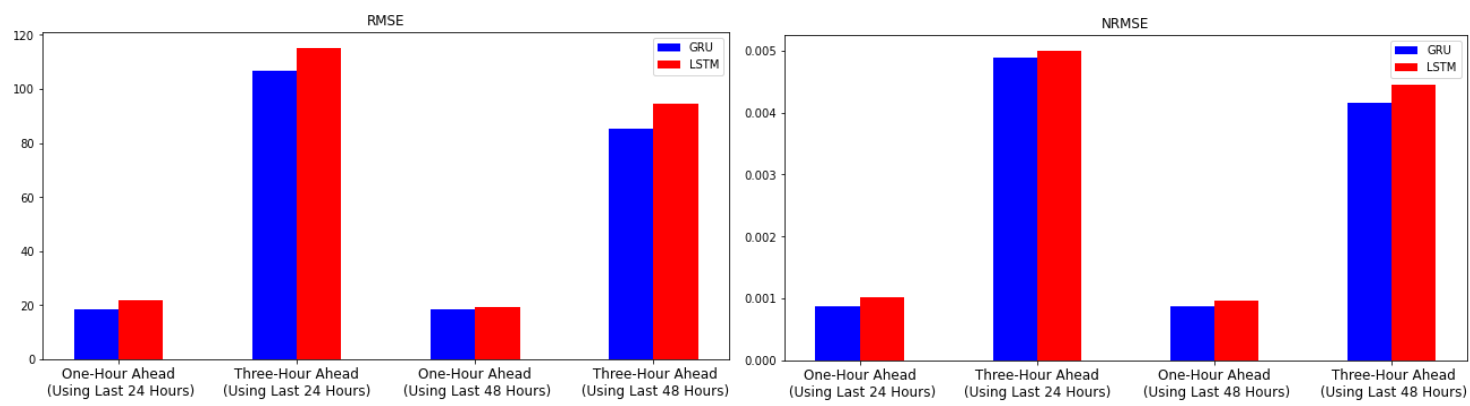

(a) (b)
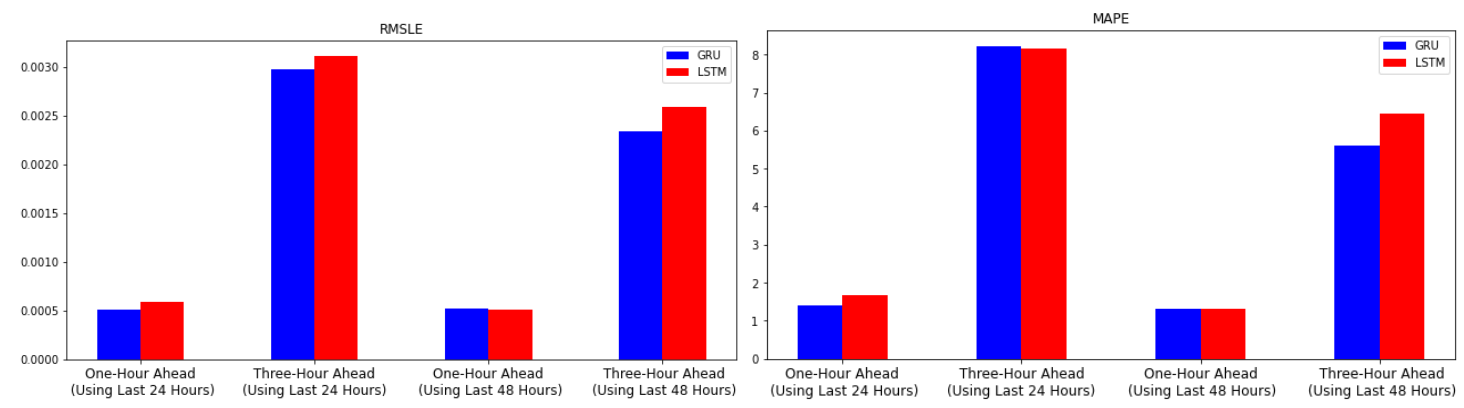

(c) (d)

Figure 9. Prediction performances of LSTM and GRU networks for one-hour and three-hour ahead forecasting energy consumption in terms of (a) RMSE, (b) NRMSE, (c) RMSLE, and (d) MAPE

\section{CONCLUSION}

In this paper, electrical energy consumption values in Turkey are predicted by employing LSTM and GRU deep neural networks. Forecasting performances of both models are compared in terms of RMSE, NRMSE, RMSLE, and MAPE metrics. On the other hand, both models have also compared in terms of computation time and the results show that GRU is better than LSTM model in terms of computation time. Numerical results show that the GRU model performs slightly better than the LSTM network. Moreover, one-hour ahead predictions are more accurate than three-hour ahead predictions. Besides, forecasting the energy consumption values using the last 48 hours gives better results than using the last 24 hours. In conclusion, we believe that deep neural networks can reliably be employed to forecast electrical energy consumption and, in this way, to manage electrical energy strategies efficiently. 


\section{REFERENCES}

[1] Koç, E., \& Şenel, M. C. (2013). Dünyada ve Türkiye'de enerji durumu-genel değerlendirme. Mühendis ve Makina Dergisi, 54(639), 32-44.

[2] Bilgili, M. (2010). Present status and future projections of electrical energy in Turkey.Gazi University Journal of Science, 23(2), 237-248.

[3] Fackrell, B. (2013). Turkey and regional energy Security on the road to 2023. Turkish Policy Quarterly, 12(2), 83-89.

[4] TUIK, Turkish Statistics Institute. (2021). Statistics, http://www.tuik.gov.tr.

[5] Turkey's Lessons for Emerging Economies - Caixin Global. http://www.caixinglobal.com,(20.01.2021).

[6] International Monetary Fund (2021). World Economic Outlook Database, October 2020. https://www.imf.org/en/home, (20.01.2021).

[7] World Bank (2021), International Comparison Program database: GDP, PPP (current international \$). https://data.worldbank.org/indicator/NY.GDP.MKTP.PP.CD, (20.01.2021).

[8] The World Factbook (2021), Real GDP (purchasing power parity). https://www.cia.gov/the-worldfactbook/field/real-gdp-purchasing-power-parity/, (23.01.2021).

[9] World Data (2021). Turkey Energy Consumption. https://www.worlddata.info/asia/turkey/energyconsumption.php, (23.01.2021).

[10] De Felice, M., Alessandri, A., \& Ruti, P. M. (2013). Electricity demand forecasting over Italy: Potential benefits using numerical weather prediction models. Electric Power Systems Research, 104, 71-79.

[11] Kavaklioglu, K., Ceylan, H., Ozturk, H. K., \& Canyurt, O.E. (2009). Modeling and prediction of Turkey’s electricity consumption using artificial neural networks. Energy Conversion and Management, 50(11), 27192727.

[12] Hamzaçebi, C., \& Kutay, F. (2004).Yapay sinir ağları ile Türkiye elektrik enerjisi tüketiminin 2010 yılına kadar tahmini. Gazi Üniversitesi Mühendislik Mimarlık Fakültesi Dergisi, 19(3), 227-233.

[13] Dilaver, Z., \& Hunt, L. C. (2011). Turkish aggregate electricity demand: An outlook to 2020. Energy, 36(11), 6686-6696.

[14] Bolturk, E., Oztaysi, B., \& Sari, I. U. (2012). Electricity Consumption Forecasting Using Fuzzy Time Series. IEEE Symposium on Computational Intelligence and Informatics. 20-22 November, Budapest, Hungary, 245-249.

[15] Tokgöz, A., \& Ünal, G. (2018). A RNN Based Time Series Approach for Forecasting Turkish Electricity Load.26 $6^{\text {th }}$ Signal Processing and Communications Applications Conference (SIU).2-5 May, Izmir, Turkey, $1-4$.

[16] Akay, D., \& Atak, M. (2007). Grey prediction with rolling mechanism for electricity demand forecasting of Turkey. Energy, 32(9), 1670-1675.

[17] Hamzacebi, C., \& Es, H. A. (2014). Forecasting the annual electricity consumption of Turkey using an optimized grey model. Energy, 70,165-171.

[18] Hu, Y. C. (2017). Electricity consumption prediction using a neural-network-based grey forecasting approach.Journal of the Operational Research Society, 68(10), 1259-1264.

[19] Yumurtacı, Z., \& Asmaz, E. (2004). Electric energy demand of Turkey for the year 2050. Energy Sour, 26(12), 1157-1164.

[20] Kavaklioglu, K. (2011). Modeling and prediction of Turkey's electricity consumption using support vector regression. Applied Energy, 88(1), 368-375.

[21] Oğcu, G., Demirel, O.F., \& Zaim, S. (2012). Forecasting electricity consumption with neural networks and support vector regression. Social and Behavioral Sciences, 58, 1576-1585.

[22] Kavaklioglu, K. (2014). Robust electricity consumption modeling of Turkey using singular value decomposition. International Journal of Electrical Power \& Energy Systems, 54, 268-276.

[23] Karaca, C., \& Karacan, H. (2016). Çoklu regresyon metoduyla elektrik tüketim talebini etkileyen faktörlerin incelenmesi. Selçuk Üniversitesi Mühendislik, Bilim ve Teknoloji Dergisi, 4(3), 182-195.

[24] Haliloğlu, E. Y., \& Tutu, B. E. (2018). Türkiye için kısa vadeli elektrik enerjisi talep tahmini. Journal of Yaşar University, 13(51), 243-255.

[25] Topalli, A. K., Erkmen, I., \& Topalli, I. (2006). Intelligent short-term load forecasting in Turkey. International Journal of Electrical Power \& Energy Systems, 28(7), 437-447.

[26] Erdogdu, E. (2007). Electricity demand analysis using cointegration and ARIMA modelling: A case study of Turkey. Energy Policy, 35(2), 1129-1146. 
[27] Demirel, Ö., Kakilli, A., \& Tektaş, M. (2010). ANFIS ve ARMA modelleri ile elektrik enerjisi yük tahmini. Gazi Üniversitesi Mühendislik-Mimarlık Fakültesi Dergisi, 25(3), 601-610.

[28] Boran, K. (2014). The Box Jenkins approach to forecast net electricity consumption in Turkey. Energy Sour A, 36(5), 515-524.

[29] Çevik, H. H., \& Çunkaş, M. (2015) Short-term load forecasting using fuzzy logic and ANFIS. Neural Computing and Applications, 26(6), 1355-1367.

[30] Ozturk, H. K., Ceylan, H., Canyurt, O. E., \& Hepbasli, A. (2005). Electricity estimation using genetic algorithm approach: a case study of Turkey. Energy, 30(7), 1003-1012.

[31] Yiğit, V. (2011). Genetik algoritma ile Türkiye net elektrik enerjisi tüketiminin 2020 yılına kadar tahmini. International Journal of Engineering Research and Development, 3(2), 37-41.

[32] Kucukali, S., \& Baris, K. (2010). Turkey's short-term gross annual electricity demand forecast by fuzzy logic approach. Energy Policy, 38(5), 2438-2445.

[33] Toksar1, M. D. (2009). Estimating the net electricity energy generation and demand using the ant colony optimization approach: case of Turkey. Energy Policy, 37, 1181-1187.

[34] Kıran, M. S., Özceylan, E., Gündüz, M., \& Paksoy, T. (2012). Swarm intelligence approaches to estimate electricity energy demand in Turkey. Knowledge-Based Systems, 36, 93-103.

[35] Kavaklioglu, K., Ceylan, H., Ozturk, H. K., \& Canyurt, O. E. (2009). Modeling and prediction of Turkey's electricity consumption using artificial neural networks. Energy Conversion and Management, 50(11), 27192727.

[36] Çunkaş, M., \& Altun, A. A. (2010). Long term electricity demand forecasting in Turkey using artificial neural networks. Energy Sour B, 5(3), 279-289.

[37] Sözen, A., Isikan, O., Menlik, T., \& Arcaklioglu, E. (2011). The forecasting of net electricity consumption of the consumer groups in Turkey. Energy Sour B, 6, 20-46.

[38] Yetis, Y., \& Jamshidi, M. (2014). Forecasting of Turkey's Electricity Consumption using Artificial Neural Network. World Automation Congress (WAC).3-7 August, Waikoloa, USA, 723-728.

[39] Günay, M. E. (2016). Forecasting annual gross electricity demand by artificial neural networks using predicted values of socio-economic indicators and climatic conditions: Case of Turkey. Energy Policy, 90, 92-101.

[40] Hamzaçebi, C., Es, H. A., \& Çakmak, R. (2019). Forecasting of Turkey's monthly electricity demand by seasonal artificial neural network. Neural Computing and Applications, 31(7), 2217-2231.

[41] Özkurt, N., Öztura, H. Ş., \& Güzeliş, C. (2020). 24-hour Electricity Consumption Forecasting for Day ahead Market with Long Short-Term Memory Deep Learning Model. $12^{\text {th }}$ International Conference on Electrical and Electronics Engineering (ELECO). 26-28 November, Bursa, Turkey, 173-177.

[42] Özbay, H., \& Dalcali, A. (2021). Effects of COVID-19 on electric energy consumption in Turkey and ANNbased short-term forecasting. Turkish Journal of Electrical Engineering \& Computer Sciences, 29(1), 78-97.

[43] Schuster, M., \& Paliwal, K. (1997). Bidirectional recurrent neural networks. IEEE Transactions on Signal Processing, 45(11), 2673-2681.

[44] Koutnik, J., Greff, K., Gomez, F., \& Schmidhuber, J. (2014). A Clockwork RNN. $31^{\text {st }}$ International Conference on Machine Learning.21-26 June, Beijing, China, 1863-1871.

[45] Cho, K., Van Merrienboer, B., Bahdanau, D., \& Bengio, Y. (2014). On the Properties of Neural Machine Translation: Encoder-Decoder Approaches. $8^{\text {th }}$ Workshop on Syntax, Semantics and Structure in Statistical Translation (SSST-8), 25 October, Doha, Qatar, 103-111.

[46] Hochreiter, S., \& Schmidhuber, J. (1997). Long short-term memory. Neural Computation, 9(8), 1735-1780.

[47] Türkünoğlu, A. (2019). Short Term Electricity Consumption Forecasting using Long Short-Term Memory Cells. Yüksek Lisans Tezi, İstanbul Teknik Üniversitesi, Enerji Enstitüsü, İstanbul.

[48] Shahid, F., Zameer, A. \& Muneeb, M. (2020). Predictions for Covid-19 with deep learning models of LSTM, GRU and Bi-LSTM. Chaos, Solitons \& Fractals, 140, 1-9.

[49] Gers, F. A., Schmidhuber, J., \& Cummins, F. (2000). Learning to forget: Continual prediction with LSTM.Neural Computation, 12(10), 2451-2471.

[50] Zeroual, A., Harrou, F., Dairi, A. \& Sun, Y. (2020). Deep learning methods forforecasting Covid-19 timeseries data: A comparative study. Chaos, Solitons \& Fractals, 140, 1-12.

[51] Chung, J., Gulcehre, C., Cho, K., \& Bengio, Y. (2014). Empirical Evaluation of Gated Recurrent Neural Networks on Sequence Modeling. NIPS 2014 Workshop on Deep Learning, 1-9.

[52] EPİAŞ Şeffaflı Platformu. Türkiye Gerçek Zamanlı Elektrik Tüketim Verileri, https://seffaflik.epias.com.tr/transparency/tuketim/gerceklesen-tuketim/gercek-zamanli-tuketim.xhtml, (15.01.2021). 